\title{
- PARTYCYPACJA KOBIET (W SZCZEGÓLNOŚCI PIELĘGNIAREK) W OGÓLNOROZWOJOWYCH FORMACH AKTYWNOŚCI FIZYCZNEJ - ANALIZA LITERATUROWA
}

\author{
PARTICIPATION OF WOMEN (PARTICULARLY NURSES) IN GENERAL FORMS OF PHYSICAL \\ ACTIVITY - LITERATURE ANALYSIS
}

\author{
Grzegorz Konieczny ${ }^{1}$, Renata Rasińska ${ }^{2}$ \\ ${ }^{1}$ Katedra Marketingu i Zarządzania \\ Wyższa Szkoła Hotelarstwa i Gastronomii w Poznaniu \\ ${ }^{2}$ Zakład Organizacji i Zarządzania w Opiece Zdrowotnej \\ Uniwersytet Medyczny im. Karola Marcinkowskiego w Poznaniu
}

DOI: https://doi.org/10.20883/pielpol.2017.44

\section{STRESZCZENIE}

Cel. Celem niniejszego opracowania jest zaprezentowanie roli i znaczenia zdrowego stylu życia, którego głównym składnikiem jest aktywność fizyczna, oraz przeprowadzenie teoretycznej analizy podstawowych pojęć związanych z analizowaną problematyką. Ponadto autorzy publikacji dokonają oceny uczestnictwa kobiet w ogólnorozwojowych formach aktywności fizycznej. Materiał i metody. Niniejsza praca ma charakter teoretyczny. Autorzy oparli ją na literaturze przedmiotu i obowiązującej w tym zakresie terminologii, co pozwoliło na przedstawienie dotychczasowego stanu wiedzy. Dodatkowo do analiz pogłębionych wykorzystano istniejące zasoby internetowe.

SŁOWA KLUCZOWE: pielęgniarki, zdrowy (prozdrowotny) styl życia, aktywność fizyczna.

\section{Wprowadzenie}

Niniejsze opracowanie z racji obiektywnych ograniczeń będących następstwem specyfiki analizowanego zjawiska, tj. jego złożoności oraz wielowymiarowości oraz trudności natury kwantytatywnej, jak i predykcyjnej, może cechować się pewnymi uproszczeniami i niepełnością analiz literaturowych. Tym niemniej, autorzy podejmują w niniejszym opracowaniu najistotniejsze problemy uznane w świetle aktualnego stanu wiedzy za wartościowe. Dotyczą one partycypacji kobiet (w szczególności pielęgniarek) w ogólnorozwojowych formach aktywności fizycznej. Ograniczono się do zaprezentowania teoretycznych ustaleń terminologicznych związanych z rolą i znaczeniem zdrowego stylu życia oraz najczęściej podejmowanymi przez kobiety (w tym pielęgniarki) formami aktywności fizycznej.

Dokonująca się na naszych oczach konwersja społeczno-kulturowa wywarła istotny wpływ na ,,tkankę

\begin{abstract}
Aim. The purpose of this paper is to present the role and importance of healthy lifestyles, the main component of which is physical activity in women's consciousness and to analyze theoretically basic concepts related to the analyzed problem. In addition, the authors will evaluate the participation of women in general developmental forms of physical activity.

Material and methods. This manuscript is of a theoretical nature. Theoretical part was based on the literature of the subject and the terminology applicable in this field, which allowed to present the current state of knowledge. In addition to in-depth analysis, existing web resources were used.
\end{abstract}

KEYWORDS: nurse, healthy lifestyle, physical activity.

społeczną", w tym na styl życia i zachowania w czasie wolnym. Zmiany te widoczne są w szeroko rozumianej kulturze fizycznej, tj. odnoszącej się do płaszczyzny rekreacji i turystyki, sportu, wychowania fizycznego, jak również rehabilitacji ruchowej.

Zmiana stylu życia, jak wynika $z$ analiz literaturowych, dotyczy zarówno mężczyzn jak i kobiet. Moda kreująca obecnie szczupłą i wysportowaną sylwetkę na ideał urody, jak wskazuje m.in. Lipowski (2000), wpływa zarówno na wzrost zainteresowania kobiet aktywnością fizyczną, jak również na zwiększające się ich uczestnictwo w rekreacji ruchowej. Jak zauważa Nowocień, zainteresowanie kulturą fizyczną oraz pozytywny stosunek do niej wykazuje aż 65,9\% kobiet [1].

Jednakże nie można bagatelizować faktu niskiej pozycji aktywności fizycznej w strukturze wolnoczasowej kobiet. Aktualnie widoczne są diametralne rozbieżności pomiędzy deklarowanymi przez kobiety potrzeba- 
mi związanymi z aktywnością fizyczną a ich realizacją (Nowocień 1996, Winiarski1997, Klementowski i wsp. 2000, Pachnowska 2001, Nowak 2002, Lipowski 2005). Potwierdzają to przeprowadzane badania, z których wynika, że czynna aktywność fizyczna pozostaje dla większości polskich kobiet jednak sferą nierealizowaną. Tylko 34,1\% systematycznie podejmuje aktywność fizyczną [1].

Aktywność fizyczna to każda praca, ruch wykonany przez mięśnie szkieletowe. Jest bardzo ważnym elementem naszego życia. Regularna aktywność fizyczna kształtuje człowieka, jego ciało, charakter i stan umysłu. Aktywne spędzanie czasu to najlepsza profilaktyka zdrowotna, jaką możemy zapewnić naszemu organizmowi. Bardzo korzystny wpływ na nasze zdrowie ma ruch na świeżym powietrzu. Osoby, które systematycznie ćwiczą, są nie tylko szczuplejsze, ale także mają lepiej dotleniony mózg, przez co lepiej zapamiętują informacje i lepiej się koncentrują. Ruch pozytywnie wpływa na układ oddechowy, krwionośny oraz układ ruchu, a ponadto usprawnia systemy kontrolujące przebieg procesów metabolicznych. Dzięki regularnym ćwiczeniom wzrasta objętość krwi w krwiobiegu. Rośnie pojemność wyrzutowa serca, co powoduje rzadsze skurcze serca w spoczynku i podczas wysiłku.

Ponadto regularna aktywność fizyczna, przede wszystkim ta, o charakterze wytrzymałościowym, wpływa także korzystnie na metabolizm lipidowy. Wysiłki takie obniżają ogólną ilość cholesterolu, zmniejszają poziom trójglicerydów i frakcji LDL-cholesterolu, natomiast powodują wzrost frakcji HDL-cholesterolu. Tym samym obniżają ryzyko wystąpienia miażdżycy tętnic oraz choroby wieńcowej serca. Te pozytywne zmiany w gospodarce lipidowej obserwuje się nawet wtedy, kiedy wysiłek jest na tyle mały, że nie wpływa istotnie na wzrost $\mathrm{VO}_{2 \max }$. Oznacza to, że nawet szybki marsz, wykonywany przez kilkadziesiąt minut 4-5 razy w tygodniu przynosi nam olbrzymie korzyści zdrowotne. Ważnym wskaźnikiem sprawności metabolicznej jest również stosunek lipidów do utlenianych węglowodanów. Jest to istotne zarówno w trakcie wypoczynku, jak i podczas wysiłków o średniej i dużej mocy. Przyjmuje się, że silniejsza oksydacja (utlenianie) lipidów może być pożądana z punktu widzenia utrzymania sprawności fizycznej, sportowych osiągnięć i kontroli masy ciała [2]. Aktywność ruchowa także korzystnie wpływa na podwyższenie w mózgu stężenia serotoniny i noradrenaliny. Implikuje to większe wytwarzanie w mózgu endorfin, tzw. hormonów szczęścia, które tłumią odczuwanie bólu, dając uczucie przyjemności i dobrego nastroju.

Zazwyczaj aktywność fizyczna implikuje sprawność fizyczną. Pojęcie „sprawności fizycznej” wiąże się zazwyczaj nie tylko z funkcją aparatu ruchu, ale z biolo- gicznym działaniem całego organizmu. Podłożem takiej sprawności są określone predyspozycje i funkcje ustroju, a po stronie przejawów sprawność fizyczna wyraża się w określonych efektach motorycznych, prawidłowościach budowy ciała, a także osobniczej aktywności fizycznej. Niezależnie więc od koncepcji teoretycznej przyjmuje się, że na sprawność fizyczną składa się nie tylko zasób opanowanych ćwiczeń ruchowych, ale i poziom wydolności wszystkich narządów i układów, zdolności motoryczne (siłowe, szybkościowe, wytrzymałościowe i koordynacyjne), a nawet pewne elementy aktywnego stylu życia. Skuteczność działania poszczególnych fizjologicznych funkcji organizmu, a w szczególności sposób przetwarzania energii oraz zdolność dostatecznego przystosowania do zmiennych warunków otoczenia mają więc tutaj pierwszoplanowe znaczenie. Można zatem przyjąć, że osoba wysoce sprawna fizycznie to taka, która dobrze opanowała ćwiczenia ruchowe, ma wysoką wydolność układu krążenia, oddychania, wydzielania wewnętrznego i termoregulacji [3].

Podstawą systemu kultury fizycznej jest wychowanie fizyczne, sport, rehabilitacja/fizjoterapia oraz turystyka i rekreacja. Poprzez powyższe wymiary kultury fizycznej realizowane są zadania zmierzające do wspomagania rozwoju fizycznego, motorycznego człowieka oraz przygotowania i wyposażenia w takie umiejętności, które pozwolą człowiekowi w poszczególnych fazach ontogenezy należycie troszczyć się o swoje ciało [Siwiński 1992, Winiarski, 1989, Wolańska, 1988]. Ponadto, jak wynika $z$ analiz literaturowych, aktywne uczestnictwo w kulturze fizycznej oraz przemyślane realizowanie zdrowego stylu życia przyczynia się do polepszania stanu zdrowia człowieka [Demel 1980, Gniazdowski 1990, Woynarowska 1993, Siwiński 2000, Żukowska, Żukowski 2003, Nowocień 2013].

Powyższe stanowisko zdaje się potwierdzać koncepcja „pól zdrowia”, przedstawiona przez kanadyjskiego ministra zdrowia M. Lalonde'a. Wynika z niej, że spośród czterech grup czynników warunkujących zdrowie człowieka (genetycznych, środowiskowych, organizacji opieki medycznej i stylu życia), styl życia, którego głównymi składnikami są: regularna i umiarkowana aktywność fizyczna, zdrowe odżywianie, niestosowania używek oraz umiejętność radzenia sobie ze stresem, stanowią spiritus movens zdrowia człowieka.

Prekursorzy pedagogiki kultury, m.in. Hessen, Nawroczyński, Suchodolski, Wołoszyn oraz Wroczyński zwracali uwage na to, że zdrowie i sprawność fizyczną należy otaczać szczególną opieką, ponieważ są niezbędne w rozwoju społecznym i biologicznym człowieka [4]. Z kolei baron de Coubertin - inicjator nowożytnych igrzysk olimpijskich w licznych publikacjach wskazywał na konieczność 
upowszechnianiasportuiwprowadzaniago,jakojednej z form kultury fizycznej do programów edukacyjnych, widząc w nim ogromny potencjał edukacyjny. Ta forma edukacji współczesnego człowieka powinna stać się nierozerwalnym elementem wychowania pojmowanego integralnie.

Ze względu na działania praktyczne wynikające z potrzeb społecznych trzeba także dostrzegać wewnętrzne zróżnicowanie kultury fizycznej. Czym innym jest bowiem wychowanie fizyczne jako środek czy metoda wychowania młodego pokolenia, czym innym rekreacja ruchowa jako czynnik podtrzymywania zdrowia i sprawności fizycznej osób w wieku produkcyjnym i poprodukcyjnym, czym innym rehabilitacja ruchowa jako czynnik przywracania zdrowia i sprawności fizycznej, a czym innym wreszcie sport wyczynowy jako czynnik wskazujący na nieograniczone możliwości psychofizyczne człowieka w zakresie specyficznej sprawności fizycznej i jako czynnik podtrzymujący „ducha” narodu [5].

Powracając jednakże do meritum należy zauważyć, że Tempora mutantur et nos mutamur in illis (Czasy się zmieniają i my zmieniamy się z nimi). W tę łacińską maksymę doskonale wpisują się kobiety $\mathrm{XXI}$ wieku, które wychodzą poza ramy ograniczające je do tradycyjnych ról żony i matki. Współczesne kobiety łamią stereotypy oraz wszechobecne mity i uprzedzenia i angażują się na płaszczyźnie zawodowej oraz uczestniczą w różnych formach życia społeczno-kulturalnego, jak również politycznego. Znacząca zmiana ról i pozycji społecznej kobiety i wypieranie modelu rodziny patriarchalnej, jak zauważa Nowocień, „,prowadzi współcześnie do kreowania układów partnerskich między małżonkami lub też układów, w których dominuje kobieta. Sytuacja taka jest efektem przemian społeczno-polityczno-ekonomicznych, jakie dokonują się w Polsce w ostatnich latach i które bardzo duży wpływ mają również na rodzinę" [6].

W wyniku analiz zintegrowanej struktury poznawczej dotyczącej jakości życia współczesnych kobiet należy zauważyć, że dla coraz większej grupy analizowanej subpopulacji aktywność fizyczna stanowi pożądany element zdrowego stylu życia. Jak zauważa Denek, „,treść i zagospodarowanie czasu wolnego jest ważnym elementem jakości życia" [7] w wymiarze fizycznym, psychicznym i społecznym. Z kolei amerykański badacz Willett ze Szkoły Zdrowia Publicznego Uniwersytetu Harvarda uważa, że codzienna aktywność fizyczna stanowi spiritus movens zdrowia [8] i tym samym umiejscawia ją u podstawy nowoczesnej piramidy zdrowia, której jest twórcą.

Taki stan rzeczy skłaniać powinien do szeroko rozumianej naukowej refleksji nad tym zjawiskiem oraz ujmowaniem tej problematyki w sposób interdyscy- plinarny. Dlatego też problematyka rekreacji i czasu wolnego znajduje się w polu zainteresowań licznej grupy badaczy, czy m.in. wybitnego specjalisty nauk o kulturze fizycznej i turystyce Siwińskiego, który w jednym ze swych opracowań przekonuje, że ,interdyscyplinarny charakter problematyki rekreacji i czasu wolnego implikuje konieczność wielostronnej analizy zjawisk i procesów zachodzących w tej dziedzinie ludzkiej działalności. Wynika to między innymi z faktu, że uczestnictwo w rekreacji ruchowej oraz należyte wykorzystanie czasu wolnego nie jest tylko sprawą swobodnego wyboru jednostki, ale ich poziom zdeterminowany jest kompleksem czynników, wśród których najistotniejsze są: wiek, dyspozycje somatyczno-motoryczne, stan zdrowia, a zwłaszcza motywacje" [9].

Współcześnie aktywność fizyczna umiejscowiona jest w nowych ramach przestrzenno-czasowych oraz stale zmieniającym się wymiarze społeczno-kulturowym. Dlatego w celu lepszego poznania wpływu tego zjawiska na współczesnego człowieka i społeczeństwo czy też skali i poziomu podejmowania aktywności fizycznej należy stale podejmować pogłębione analizy implikacyjne i ewaluacyjne o charakterze toposu ze strony różnych środowisk naukowych. Właściwe kierowanie funkcjonowaniem rekreacją ruchową oraz czasem wolnym jest możliwe tylko wtedy, gdy nabędzie się wiedzę o charakterze interdyscyplinarnym.

Nieustanna analiza procesów konwersji społeczno-kulturowej oraz tworzenia, dostosowywania oraz popularyzowania już istniejących programów edukacyjnych, jak również podejmowania takich działań wychowawczych, które by młodego człowieka uwrażliwiły na pozytywne wartości wynikające z aktywnego uczestnictwa w różnych formach kultury fizycznej i stały się asumptem dla dzieci i młodzieży do większego udziału w nich.

Tak zaplanowana edukacja i wychowanie ,ku człowiekowi" zmierzać będzie jak podkreśla w swojej nauce Karol Wojtyła - Jan Paweł II do ,wolnego i odpowiedzialnego" [10] wyboru wartości lokujących się w tym obszarze aktywności życia.

\section{Podstawowe pojęcia}

\section{Zdrowy (prozdrowotny) styl życia}

Przechodząc do analizy pojęcia zdrowy (prozdrowotny) styl życia na wstępie należy nadmienić, że w literaturze przedmiotu jest on określany jako „przyjęcie wzorów świadomych zachowań związanych ze zdrowiem, będących efektem wyborów dokonywanych przez ludzi na podstawie dostępnych, determinowanych ich sytuacją życiową alternatyw [11]. Ponadto prozdrowotny styl życia obiektywizuje się poprzez uczestnictwo w różnorodnych 
formach aktywności fizycznej. Literatura przedmiotu definiuje ten termin jako „wzory świadomych zachowań związanych ze zdrowiem, będących efektem wyborów dokonywanych przez ludzi na podstawie dostępnych, determinowanych ich sytuacją życiową alternatyw; nie tylko wzory zachowań związanych ze zdrowiem, ale także wartości i postawy reprezentowane przez ludzi w odpowiedzi na warunki ich społecznego, kulturowego i ekonomicznego środowiska" [12].

\section{Aktywność fizyczna}

Należy na wstępie zauważyć, że aktywność fizyczna jest to najważniejszy po odżywianiu czynnik determinujący zdrowie. W doskonaleniu autosystemów regulacyjnych organizmu stawiana jest bezsprzecznie na pierwszym miejscu. Jest ona czynnikiem modelującym w sposób najbardziej korzystny stan morfologiczny i funkcjonalny organizmu, a także istotnym czynnikiem kształtującym cechy psychiczne". Osiński dodaje, że aktywność fizyczna ,podejmowana systematycznie w istotnym stopniu wpływa na zachowanie, a także umacnianie zdrowia człowieka [13].

Ponadto, jak konstatuje Woynarowska, ,,aktywność fizyczna stymuluje i wspomaga rozwój:

- $\quad$ somatyczny - poprzez rozwój mięśni, zwiększając ich siłę i sprężystość; pomaga budować i wzmacniać siłę kości, wpływając na ich mineralizację; wzmacnia i stabilizuje stawy; poprawia koordynację ruchową; zapewnia harmonijny rozwój (proporcjonalne przyrosty masy ciała); zwiększa pojemność życiową płuc; kształtuje lepszą pracę serca; obniża ciśnienie tętnicze krwi, kształtuje dobrą sprawność fizyczną;

- $\quad$ psychoemocjonalny - poprzez poprawę pamięci, dobrego samopoczucia; uczy radzenia sobie ze zmęczeniem i stresem, korzystnie wpływa na postępy w nauce (oceny, zachowanie, koncentracja uwagi), zmniejsza poziom lęku, obniża stany depresyjne;

- $\quad$ społeczny - kształtuje relacje z innymi, sprzyja tworzeniu pozytywnych zachowań w ramach idei „fair play”, uczy wygrywać i przegrywać, uczy się współpracy, samokontroli, może być dobrym sposobem spędzenia czasu z rówieśnikami [14].

Istnieje wiele wykładni czy horyzontów interpretacyjnych dla tego, co nazywamy aktywnością fizyczną. Termin ,aktywność fizyczna” rozumiana jest jako aktywność w czasie wolnym o charakterze rekreacji, sportu, ćwiczeń lub rozrywki i wypoczynku. Ponadto $z$ analiz literaturowych wynika, że aktywność fizyczna to różnego rodzaju zajęcia związane z wykonywaniem przez mięśnie szkieletowe ruchów, powodujących wyda- tek energetyczny, wyższy niż w spoczynku. Do zajęć tych należą: czynności związane z wykonywaniem określonej pracy (np. zamiatanie, podnoszenie, kopanie), związane z przemieszczaniem się (np. chodzenie, jazda na rowerze), wypoczynkiem (np. uprawianie ogródka, jazda na wrotkach) [15]. Z kolei Przewęda konstatuje, że „mianem aktywności ruchowej lub fizycznej określa się wysiłek mięśniowy wywołujący w organizmie zespół zmian, które prowadzą do wydatku energetycznego wyższego niż poziom spoczynkowy" [16]. Aktywność fizyczna cechuje się zachowaniem celowo ukierunkowanym [17], w odróżnieniu od aktywności ruchowej, w której czynności zazwyczaj są mechaniczne lub automatyczne.

Aktywność fizyczna nierozerwalnie łączy się z treningiem fizycznym. Zdaniem Hübner-Woźniaka jest on „,wielopoziomową i kompleksową aktywnością, której celem jest uzyskanie długofalowych, a także adaptacyjnych zmian w organizmie. Zmiany te służą osiąganiu najkorzystniejszych korzyści zdrowotnych" [18]. Z literatury przedmiotu wynika, że istnieją następujące formy treningów: trening ogólnorozwojowy, trening siły mięśniowej, trening szybkości oraz trening wytrzymałościowy [19].

Zdaniem Cendrowskiego istotą wszelkiej aktywności fizycznej jest: aktywność, która dostarcza radości, zadowolenia, przyjemnych wrażeń, umożliwia odprężenie, relaks, obniżenie poziomu samokontroli emocjonalnej, dobrowolność - poczucie swobody wyboru i możliwości działania w zgodzie z własnymi preferencjami i zamiłowaniami, odmienność - w stosunku do obowiązków wynikających z pełnienia ról społeczno-zawodowych, bezinteresowność - brak motywów ekonomicznych przy podejmowaniu aktywności fizycznej czy też działań rekreacyjnych, zabawa i rozrywka - możliwość oderwania się codzienności, tj. przeniesienia się do świata zabawy, gdzie podejmuje się czynności dla przyjemności [20]. Współcześnie istnieje kilka kryteriów klasyfikacji form fitness. Podstawowym podziałem jest rozgraniczenie fitness wyczynowego i rekreacyjnego. Wśród form fitness rekreacyjnego wskazać należy zajęcia: indywidualne, zespołowe oraz zajęcia w siłowni. Zespołowe zajęcia fitness są właśnie głównym tematem niniejszego artykułu. Zajęcia fitness można również podzielić następująco: na formy przeprowadzane z muzyką lub bez niej, z wykorzystaniem przyborów lub bez, zajęcia taneczne oraz bez choreografii, formy ogólnorozwojowe lub formy kształtujące sylwetkę lokalnie.

Ponadto aktywność fizyczna dzieli się na ,codzienną (spontaniczną) oraz zaplanowaną. Wydatek energetyczny związany z aktywnością fizyczną dotyczy zarówno celowo wykonywanych ćwiczeń fizycznych (aktywność ruchowa związana z ćwiczeniami), jak też codziennej porcji ruchu, którą każdy człowiek wykonuje, 
nie zastanawiając się nad tym $\mathrm{np}$. chodzenia, siadania, wstawania (aktywność fizyczna niezwiązana z ćwiczeniami lub spontaniczna aktywność ruchowa [21]".

Należy nadmienić, że na aktywność fizyczną jako zachowanie społeczne człowieka wpływają czynniki osobnicze oraz środowiskowe (naturalne). Oznacza to, że spiritus movens aktywności fizycznej umiejscowiony jest w człowieku, jak i poza nim. Koherencja powyższych czynników powoduje, że muszą zachodzić między nimi wzajemne interakcje.

Jak wynika z ekologicznego modelu aktywności fizycznej, człowiek otoczony jest czterema systemami: mikrosystemem, mezosystemem, egzosystemem oraz makrosystemem. Pierwszy z nich odgrywa największą rolę dla człowieka, gdyż jest to jego najbliższe otoczenie, np. rodzina, szkoła, rówieśnicy. Do tej grupy zalicza się także czynniki fizyczne, takie jak zasoby materialne rodziny, infrastruktura związana z aktywnością fizyczną w pobliżu miejsca zamieszania, np. place zabaw, boiska. Bardziej oddalony od jednostki jest mezosystem, który opiera się na wzajemnych interakcjach pomiędzy np. rodziną i szkołą, rodzicami a nauczycielami. Ścisły kontakt między tymi składnikami systemu stanowić może asumpt dla młodego człowieka w obszarze partycypacji w ogólnorozwojowych formach aktywności fizycznej. Kolejny poziom w powyższym modelu odnosi się do egzosystemu. Konstytuują go interakcje między dwoma lub większą liczbą mikrosystemów. Przynajmniej jeden z tych elementów nie musi mieć bezpośredniego wpływu na człowieka. Czwarty a zarazem najbardziej oddalony poziom dotyczy makrosystemu. Makrosystem otacza mikro-, mezo- i egzosystem. Na ten poziom składają się czynniki społeczno-kulturowe, tradycje, zwyczaje i obyczaje panujące w danym społeczeństwie, obowiązujący system aksjologiczny. W skład tego systemu wchodzą także działania instytucji lokalnych, jak i centralnych, przyczyniające się do rozwoju i polepszania zasobów wspomagających uczestniczenie w kulturze fizycznej. Wśród czynników środowiskowych i pogodowych należy wymienić także położenie geograficzne, akweny wodne, parki i tereny rekreacyjne oraz klimat.

\section{Analiza literaturowa}

W perspektywie aktualnego stanu wiedzy należy skonstatować, że udział kobiet w ogólnorozwojowych formach aktywności fizycznej jest wynikiem kilku składowych. Jedną z nich jest dążenie do stereotypów społecznych, związanych z wzorcem współczesnej kobiety preferującej model smukłej, zgrabnej sylwetki oraz zadbane ciało [22], a przez to wewnętrznego zadowolenia z osiągniętych efektów i lepszego samopoczucia.
Oczekiwanie od rekreacji fizycznej wyłącznie efektów estetyczno-sprawnościowych czy nawet zdrowotnych nie obejmuje pełnej gamy celów i zadań kultury fizycznej wobec kobiety dnia dzisiejszego [23]. Jak zauważa Parnicka, współczesna kobieta, aby „,sprostać obowiązkom, jakie narzucają jej role rodzinne i zawodowe", powinna systematycznie podejmować aktywność fizyczną. W tym kontekście aktywność fizyczna nie jest formą luksusu, ale elementarnym nakazem i koniecznością życiową, uzupełniającą jej aktywność zawodową i rodzinną.

Ponadto rudymentarnymi motywatorami udziału kobiet w szeroko rozumianej kulturze fizycznej są takie czynniki jak: troska o zdrowie, ,uspokojenie" systemu nerwowego oraz dążenie do podwyższenia poziomu sprawności fizycznej i kondycji fizycznej.

Analiza zajęć Polaków w czasie wolnym pokazuje, że w 2014 roku aż 67\% pracujących Polaków w czasie wolnym korzysta regularnie z Internetu, $21 \%$ czas ten głównie przeznacza na czytanie książek, a 10\% udaje się w tym czasie do kina [24].

Natomiast z badań przeprowadzonych przez Parnicką na próbie 2090 kobiet czynnych zawodowo wynika, że czas wolny w zdecydowanej większości poświęcają na spacery (same bądź z dziećmi), zaś turystyka i jazda na rowerze realizowana jest raczej sporadycznie [23]. Pozostałym formom aktywności ruchowej respondentki poświęcają zdecydowanie mniej uwagi.

Z powyższych analiz wyłania się obraz nacechowany syndromem pasywnej aktywności fizycznej, gdyż badani Polacy przede wszystkim w czasie wolnym korzystają z Internetu czy też czytają książki. Podobne dane wykazują badania przeprowadzone w 2007 roku przez Woynarowską. Badane osoby głównie oglądają telewizję i korzystają z Internetu (52\% wskazań), ponadto 36 \% angażuje się w życie rodzinne. Aż 27\% respondentów w czasie wolnym siedzi w domu lub leży odpoczywając. Tylko 24\% wybiera w czasie wolnym spacery [25].

Warto nadmienić, że intensywne wysiłki (sporty wyczynowe) w czasie wolnym podejmuje zaledwie 5,6\% Polaków, w tym czterokrotnie więcej mężczyzn niż kobiet [25]. Mimo niewielkiego udziału kobiet w sportach wyczynowych, jak zauważają teoretycy kultury fizycznej i wychowania fizycznego, zmiany kulturowo-społeczne, a wraz z nimi zmiany ról społecznych i zawodowych kobiet i mężczyzn powodują unifikację płci w kulturze fizycznej. Z kolei socjologowie oraz psycholodzy w związku z powyższymi zmianami ,obawiają się maskulinizacji sylwetki kobiet trenujących »męskie « dyscypliny sportu, zagrożeń dla funkcji rozrodczych kobiety oraz złamania kanonów estetycznych. Jako zasadnicze przytaczają argumenty o rolach społecznych, „naturalnych« predyspozycjach do ekspresji ruchowej i rów- 
nie »naturalnym « braku predyspozycji do walki i agresji sportowej, odmienności biologii kobiety od biologii mężczyzn" [26].

Z badań przeprowadzonych w 2008 roku przez Wojciechowską i Sudę wynika, że 36,1\% ankietowanych pielęgniarek prowadzi zdrowy styl życia wymiarem którego jest $m$.in. podejmowanie aktywności fizycznej [27]. Dla pozostałych kobiet, niepodejmujących rekreacji fizycznej, barierami są najczęściej takie czynniki jak np. brak czasu spowodowany podejmowaniem dodatkowych dyżurów, koniecznością podnoszenia kwalifikacji zawodowych czy obowiązkami domowymi.

Z kolei z badań przeprowadzonych w 2010 roku przez Bergier i wsp. wynika, że wskaźnik aktywności fizycznej pielęgniarek różni się znacznie od wskaźnika pozostałych grup zawodowych. Jest on zdecydowanie wyższy, co może świadczyć o wiedzy na temat wartości wynikających z uczestniczenia w aktywności fizycznej i jej pozytywnego wpływu na zdrowie człowieka oraz społecznym uznaniu i akceptacji różnych form kultury fizycznej. Okazuje się, że 73,2\% respondentek wskazuje na wysoki poziom uczestnictwa w ogólnorozwojowych formach aktywności fizycznej, a na umiarkowany poziom wskazuje $26,8 \%$ badanych kobiet, przy czym wyłącznie na udział w zajęciach sportowo-rekreacyjnych wskazuje $21 \%$ badanych pielęgniarek [28].

Z badań przeprowadzonych przez CBOS w 2010 roku czas wolny $69 \%$ Polek pracujących wynosi do 20 godz. tygodniowo, 18\% wskazuje na 21-49 godz. tygodniowo i tylko 5\% respondentek uważa, że dysponuje ponad 40-godzinnym czasem wolnym w tygodniu [29].

Z powyższych tez wywnioskować można, że głównym powodem abstynencji ruchowej lub niskiego poziomu uczestnictwa w aktywności ruchowej jest deficyt czasu wolnego. Potwierdzają to również dane GUS [30] z 2008 r.: 31,9\% Polaków wskazało na brak czasu jako główną przyczynę niepodejmowania jakiejkolwiek aktywności ruchowej. Badania Eurobaromentru [31] z roku 2009 także są potwierdzeniem powyższej tezy, gdyż $46 \%$ respondentów wskazuje na brak czasu wolnego jako podstawową przyczynę nieuprawiania sportu.

Tymczasem, jak zauważa Kocemba „wskazywanie na brak czasu jako na obiektywną przeszkodę uczestnictwa w kulturze fizycznej jest klasyczną racjonalizacją poglądów i ukrywaniem bardziej autentycznych powodów preferowania innego typu zajęć". Kolejnym ograniczeniem, utrudniającym systematyczne podejmowanie aktywności fizycznej, jest zły stan zdrowia, choroba lub niepełnosprawność jednostki, co często wyklucza ją niemal zupełnie z uprawiania sportu. Badania wskazują także na niechęć części społeczeństwa do podejmowania jakichkolwiek ćwiczeń [32].

\section{Podsumowanie}

Podsumowując zaprezentowane tezy, stwierdzić można, że badania nad aktywnością fizyczną kobiet, w tym i pielęgniarek, dotyczą wielu płaszczyzn zjawisk i aspektów. Istotne opracowania na temat uczestnictwa kobiet w kulturze fizycznej wiążą się z takimi nazwiskami jak: Humen (1965), Zawadzka (1990), Nałęcka (1996), Klementowski i wsp. (2000), Pelc (2000), RodziewiczGruhn (2000), Drygas i wsp. (2001), Salita (2003), Królikowska (2003), Lipowski (2005), Parnicka (2003, 2004). W życiu współczesnego człowieka istotną sferą życia stało się właściwe podejście i racjonalne korzystanie z czasu wolnego. Problem ten widoczny jest w różnych grupach społeczno-demograficznych. Badania przeprowadzone przez Woźniakiewicza (1993), Żyromską i wsp. (2001) oraz Parnicką (2004) potwierdzają powyższą konstatację. Wyniki tych badań wskazują, że pomimo obserwowalnego zjawiska wzrostu wolnego czasu w świadomości współczesnego człowieka istnieje przekonanie o jego stałym deficycie. Przyczyną tego stanu rzeczy jest przede wszystkim zła organizacja czasu poza pracą i jego nieefektywne wykorzystywanie. Jak wykazują analizy literaturowe, przeprowadzone m.in. przez Nowocienia (1996) i Stasik (2010), zarówno kobiety, jak i mężczyźni czas wolny najczęściej spędzają w domu (przed komputerem). Rzadziej są to formy plenerowe oraz czynne systematyczne uczestnictwo w ogólnorozwojowych zajęciach ruchowych. Z przeprowadzonych analiz wynika, że istnieje korzystny dyferencjał w tej kwestii w odniesieniu do kobiet pracujących w zawodzie pielęgniarki.

\section{Piśmiennictwo}

1. Nowocień J. (red.) Społeczno-edukacyjne oblicza olimpizmu. Ruch olimpijski i niepełnosprawni sportowcy, t. I. Warszawa: AWF PKOI; 1996. 79, 95.

2. Zając A, Waśkiewicz Z. Dietetyczno-treningowe wspomaganie zdrowia i sprawności fizycznej. Katowice: Wydawnictwo UKiP J\&D Gębka; 2001. 13.

3. Żarnowska A, Szwarc A (red.) Kobieta i kultura wolnego czasu. Warszawa: DiG; 2001. 79.

4. Nowocień J. Studium o pedagogice kultury fizycznej. Warszawa: Wyd. AWF w Warszawie; 2013. 69.

5. Smorawiński J. Problemy kultury fizycznej w Polsce (stan aktualny, perspektywy, zadania) W: Rekreacja i turystyka. Współczesne dylematy, zadania i perspektywy. Poznań: Pol. Stow. Nauk. Animacji Rekr. i Turyst.; 2001. 89.

6. Nowocień J. Wpływ przemian ekonomiczno-społecznych w Polsce na uczestnictwo w kulturze fizycznej kobiet pracujących. W: Umiastowska D. (red.) Aktywność ruchowa ludzi w różnym wieku. Szczecin: TKKF; 1996. 75.

7. Denek K. Pedagogiczne aspekty czasu wolnego. Lider, nr 12; 2006.

8. Willett Walter C. Harvard School of Medicine.2001. 67. 
9. Siwiński W. Współczesne problemy turystyki i rekreacji w badaniach empirycznych nauk społecznych. Warszawa: Wyd. Almamer WSE; 2007. 168.

10. K. Wojtyła. Osoba i czyn oraz inne studia antropologiczne. Lublin Towarzystwo Naukowe KUL:1994. 34.

11. Cockerham W. New directions in lifestyle research Int. J. Public Health 2007;52:327-328.

12. Ostrowska A. Styl życia a zdrowie: z zagadnień promocji zdrowia. Warszawa: Wyd. Instytutu Filozofii i Socjologii PAN; 1999. 27.

13. Bojar I, Wojtyła K, Owoc A. Aktywność fizyczna uczniów szkół podstawowych powiatu miasta Kalisz i powiatu kaliskiego, Med Ogólna 2010; 16 (XLV), 1: 33.

14. Woynarowska B. Aktywność fizyczna. W: Woynarowska B (red.) Profilaktyka w pediatrii. Warszawa: PZWL; 2008. 116.

15. Ward DS, Saunders RP, Pate RR. Physical activity interventions in children and adolescents. Human Kinetics Publ $2007 ; 127$.

16. Przewęda R. Promocja zdrowia przez wychowanie fizyczne. W: Karski JK. (red.). Promocja zdrowia. Warszawa: Ignis; 1999. 201.

17. Drabik J. Profilaktyka zdrowia - aktywność fizyczna czy aktywność ruchowa. Wychowanie fizyczne i zdrowotne. Gdańsk: AWFiS; 2011. 5.

18. Hübner-Woźniak E. Ocena wysiłku fizycznego oraz monitorowanie treningu sportowego metodami biochemicznymi. Warszawa: Wyd. AWF w Warszawie; 2006. 72.

19. Górski J. Fizjologia wysiłku i treningu fizycznego. Warszawa: PZWL; 2012. 88-96.

20. Cendrowski A. Przewodzić innym. Poradnik dla liderów zdrowia i sportu. Warszawa: Agencja Promo-Lider; 1997. 58.

21. Mazur J. (red.). Aktywność fizyczna młodzieży szkolnej w wieku 9-17 lat, aktualne wskaźniki, tendencje ich zmian oraz wybrane zewnętrzne i wewnętrzne uwarunkowania, cz. I : Badania ilościowe. Warszawa: Instytut Matki i Dziecka; 2013. 14, 152.

22. Salita J. Uczestnictwo kobiet w rekreacji ruchowej. Sport dla Wszystkich 2000; 6 .

23. Parnicka U. Motywy uczestnictwa w aktywności ruchowej kobiet czynnych zawodowo. W: Dąbrowski A. (red.). Uczestnictwo Polaków w rekreacji ruchowej i jego uwarunkowania. Warszawa, Płock: Akademia Wychowania Fizycznego Józefa Piłsudskiego w Warszawie i Szkoła Wyższa im. Pawła Włodkowica w Płocku; 2003. 82-85.

24. Boguszewski R. Aktywności i doświadczenia Polaków w 2014 roku. Komunikat z badań CBOS 12/2015. www.nck. $\mathrm{pl} /$.../Aktywności\%20i\%20doświadczenia\%20Polaków\%20 w\%202014\%20r(data dostępu 07.03.2016).
25. Woynarowska B. Zdrowe odżywianie i aktywność fizyczna. W: Woynarowska B. (red.), Edukacja zdrowotna. Warszawa: PWN; 2007. 68.

26. Brożek Z, Kwilecka M. Miejsce kobiet w kulturze fizycznej i wychowaniu fizycznym. W: Kiełbasiewicz-Drozdowska I, Marcinkowski M, Siwiński W. (red.) Aktywność rekreacyjna, sportowa i turystyczna w różnych środowiskach społecznozawodowych. Diagnoza i propozycje rozwiązań. Poznań: Pol. Stow. Nauk. Anim. Rekr. Turyst.; 2000.174.

27. Wojciechowska M, Suda K. Promocja zdrowego stylu życia nie tylko zadaniem zawodowym pielęgniarki, ale także odpowiedzią na współczesne zagrożenia zdrowia. Probl Piel 2008; 16 (1, 2). 63.

28. Bergier J, Bergier B, Soroka A, Kubińska Z. Aktywność fizyczna pielęgniarek z uwzględnieniem ich wieku, Med Ogólna 2010; 16 (XLV) 4: 597-600.

29. Stasik A. Opracowanie nt. Czas wolny Polaków. Sondaż CBOS, Warszawa: CBOS; 2010. 3.

30. Pankowski K. Polak zadbany, troska o sylwetkę i własne ciało. Komunikat $z$ badań CBOS BS/130/2009. cbos.pl/SPISKOM. POL/2009/K_130_09.PDF(data dostępu 07.03.2016).

31. Eurobarometr 72.3 Sport and Physical Activity, Results for Poland http://ec.europa.eu/public_opinion/archives/ebs/ebS_334_fact_pl_en.pdf. (data dostępu 07.03.2016).

32. Leszczyńska A. Sport to zdrowie! Refleksje o aktywności fizycznej Polaków, Acta Universitatis Lodziensis [w:] Folia Sociologica 45 2013: 184.

Artykuł przyjęty do redakcji: 13.06 .2016

Artykuł przyjęty do publikacji: 25.08.2016

Źródło finansowania: Praca nie jest finansowana z żadnego źródła. Konflikt interesów: Autorzy deklarują brak konfliktu interesów.

Adres do korespondencji:

Renata Rasińska

ul. Mariana Smoluchowskiego 11

60-179 Poznań

tel.: 618612254

e-mail: rasinska@ump.edu.pl

Zakład Organizacji i Zarządzania w Opiece Zdrowotnej

Uniwersytet Medyczny im. Karola Marcinkowskiego w Poznaniu 